\title{
Hemoglobin Level, Energy Intake, and Body Mass Index of Kebersihan, Keindahan, Kenyamanan Lingkungan Workers in an Academic Institution
}

\author{
Carmelia Cantika Maharani, ${ }^{1}$ Reni Farenia, ${ }^{2}$ Pandji Irani Fianza ${ }^{3}$ \\ ${ }^{1}$ Faculty of Medicine Universitas Padjadjaran, ${ }^{2}$ Department of Anatomy, Cell Biology and \\ Physiology Faculty of Medicine Universitas Padjadjaran ${ }^{3}$ Department of Internal Medicine \\ Faculty of Medicine Universitas Padjadjaran/Dr. Hasan Sadikin General Hospital Bandung
}

\begin{abstract}
Background: Productivity is a priority that is required from every worker. Work productivity of each person is different. The important factors of work productivity are hemoglobin level, energy intake, and body mass index (BMI). The objective of the study was to identify hemoglobin level, energy intake, and BMI of Kebersihan, Keindahan, Kenyamanan Lingkungan (K3L) workers in Universitas Padjadjaran, Jatinangor.

Methods: A descriptive study was carried out to 80 K3L workers in Universitas Padjadjaran on October 2014. The total number of 80 workers was chosen with cluster random method. Primary data consisted of hemoglobin level measured by Hemocue ${ }^{\circledR} \mathrm{Hb} 201+$, dietary consumption recall (2x24 hours), and anthropometry data (weight and height). The collected data were analyzed and presented by frequency tabulation and percentage.

Results:The study showed that more than a half of subjects (77\%) had normal hemoglobin level. The majority of subjects (47\%) had low energy intake. Most of subjects (59\%) had normal BMI, $12 \%$ subjects were underweight, $18 \%$ subjects were overweight, and $11 \%$ subjects were obesity.

Conclusions: The majority of K3L workers have normal hemoglobin level, energy intake deficiency, and normal BMI.
\end{abstract}

Keywords: Body mass index, energy intake, hemoglobin.

\section{Introduction}

Productivity is a priority that is required from every worker. Internal factors that determine work productivity consist of health, nutrition, education, and motivation of workers. Health factors which related significantly to work productivity is hemoglobin level in blood. ${ }^{1}$ Low hemoglobin level will reduce the ability to perform physical activity due to decrease of oxygen exchange efficiency in skeletal muscle. Thus, anaerobic metabolism occurs and it produces lactic acid. ${ }^{2}$ The accumulation of lactic acid leads to muscle fatigue and slow muscle work continuity, hence decrease the work capacity. ${ }^{2}$

Wolgemuth et al. ${ }^{1}$ showed that $1.3 \mathrm{~g} / \mathrm{dl}$ increase in hemoglobin level was associated with 5.6\% significant productivity gains of road workers in Kenya. Besides hemoglobin level, energy intake has an important role in work productivity. Deficiency energy intake leads to lack energy to work and do activities. ${ }^{3}$ Study had shown that energy deficiency may decrease work capacity ;thus decrease work productivity. ${ }^{4}$ Workers who have normal body mass index (BMI) would have higher productivity rather than those who have underweight and overweight $\mathrm{BMI}^{3,5,6}$ Underweight BMI indicates chronic energy deficiency meanwhile overweight and obese BMI make workers slow and inhibit in work.

Universitas Padjadjaran as one of the leading academic institutions/universities in Indonesia, has Kebersihan, Keindahan, Kenyamanan Lingkungan (K3L) workers who has important role in keeping the university tidy and clean. The K3L workers consist of 415 workers ,and were already divided into eight group based on different working area. Each working area has different coverage, ranged between $15.682 \mathrm{~m}^{2}$ to $81.288 \mathrm{~m}^{2}$.

Correspondence: Carmelia Cantika Maharani Faculty of Medicine, Universitas Padjadjaran, Jalan Raya BandungSumedang Km.21, Jatinangor, Sumedang, Indonesia, Phone: +6287774623773 Email: carmeliacantika@gmail.com 
Therefore, each worker has $341 \mathrm{~m}^{2}-1,767 \mathrm{~m}^{2}$ working area. The K3L workers work from 7 a.m. until 3 p.m. Wide working area and long working hours make K3L workers need to be healthy, so they have an optimal condition; thus leads to high productivity. An indicator of K3L workers' productivity can be observed by their attendance record. Mean attendance of workers in a month reached 65-85\%. According to the interview with chief of K3L, he stated that many workers only worked for half day.

The objective of the study was to identify the hemoglobin level, energy intake, and BMI of Kebersihan, Keindahan, Kenyamanan Lingkungan (K3L) workers in Universitas Padjadjaran, Jatinangor.

\section{Methods}

This study was carried out using descriptive method on October 2014 in Jatinangor. The population of this study was 415 of K3L workers. The criteria of study sample were K3L workers who work in Universitas Padjadjaran Jatinangor in 2014. The total number of 80 workers was chosen with cluster random method. Ten workers were chosen randomly from each eight working area.

Primary data consisted of hemoglobin level, energy intake, and anthropometry data (weight and height). Blood samples were taken for hemoglobin measurement using peripheral blood. Hemoglobin level was measured by Hemocue ${ }^{\circledR}$ Hb 201+ then classified into world Helath Organization (WHO) category. Energy intake measured by 24 hours dietary recall (2x24 hours). Dietary habits were investigated to determine the adequacy of workers' diet particularly for calories. The interviewer investigated all of food consumed by subjects in the last 24 hours for two times without consecutive manner. Data were collected in household measurements then it converted into gram unit. Then the dietary data were analyzed by using Nutrisurvey application. The energy intake data from the application were categorized into Recommended Daily Allowance (RDA) 2004.7 Meanwhile the height was measured by microtoise (accuracy $0.5 \mathrm{~cm}$ ) and weight was measured by weight scales Camry (accuracy $0.1 \mathrm{~kg}$ ). After that, BMI was calculated by equation weight $(\mathrm{kg})$ / height2 (m2). The result would be classified into BMI category according to Ministry of Health Republic of Indonesia 2003.

This study had been approved by Health Research Ethics Committee Faculty of Medicine Universitas Padjadjaran.

\section{Results}

Study samples were 80 workers with equal proportions between females and males, $40 \quad(50 \%)$ workers. Study subjects were differentiated into females and males because of having differentiation in cut off hemoglobin, energy intake, and BMI categories. All of the study subjects were in productive age. Productive age ranged from 15 to 64. Most of study subjects were in age group 30-49. Mean of the age of study subjects was 37. Age factors should be concerned because it has influence in energy intake requirement of each individual.

Table 1 Characteristics of Study Subjects $(n=80)$

\begin{tabular}{lcccc}
\hline Characteristics & $\begin{array}{c}\text { Females } \\
\mathbf{n = 4 0}\end{array}$ & $\begin{array}{c}\text { Males } \\
\mathbf{n = 4 0}\end{array}$ & $\begin{array}{c}\text { Total } \\
\mathbf{n = 8 0}\end{array}$ & $\mathbf{\%}$ \\
\hline Age (year) & & & & \\
$19-29$ & 7 & 18 & 25 & 31 \\
$30-49$ & 29 & 17 & 46 & 58 \\
$50-64$ & 4 & 5 & 9 & 11 \\
Educational background & & & & \\
Not graduated from elementary school & 6 & 4 & 10 & 13 \\
Elementary school & 19 & 17 & 36 & 45 \\
Junior high school & 10 & 11 & 21 & 26 \\
Senior high school & 5 & 8 & 13 & 16 \\
\hline
\end{tabular}


Table 2 Frequency Distribution of Hemoglobin Level Category

\begin{tabular}{lcccccc}
\hline \multirow{2}{*}{$\begin{array}{c}\text { Hemoglobin level } \\
\text { category }\end{array}$} & \multicolumn{2}{c}{ Females } & \multicolumn{2}{c}{ Males } & \multicolumn{2}{c}{ Total } \\
\cline { 2 - 7 } & $\mathbf{n}$ & $\mathbf{\%}$ & $\mathbf{n}$ & $\mathbf{\%}$ & $\mathbf{n}$ & $\mathbf{\%}$ \\
\hline Low & 11 & 28 & 7 & 18 & 18 & 23 \\
Normal & 29 & 72 & 33 & 82 & 62 & 77 \\
Total & 40 & 100 & 40 & 100 & 80 & 100 \\
\hline
\end{tabular}

The classification of age group was adjusted with age category in RDA (2004). Almost half of the study subjects (45\%) had the last educational background in elementary school and even $13 \%$ had not finished elementary school (Table 1).

Mean of hemoglobin level of females subjects was $12.76 \pm 1.35 \mathrm{~g} / \mathrm{dl}$. Instead, mean of hemoglobin level of males subjects was $14.19 \pm 1.48 \mathrm{~g} / \mathrm{dl}$.

As shown in table 2, most of the study subjects had normal hemoglobin. 23\% subjects had low hemoglobin level, consist of $28 \%$ females and $18 \%$ males. Frequency of low hemoglobin or anemia was greater in females than males.

As shown in table 3 , the lowest mean energy intake was recorded in 19-29 age group females and 50-64 age group males. In females subject, the highest mean energy consumption level was presented in 30-49 age group females, and 19-29 age group males.

As shown in table 4, $37(47 \%)$ study subjects had less energy intake than the recommendation. Females subjects have greater number of workers who had exceeded energy intake category than males. The frequency of study subjects that had exceeded energy intake was $13 \%$.

Means of BMI study subjects were $24.79 \pm 4.16$ in females and $20.60 \pm 4.04$ in males. The highest BMI was presented by females and the lowest BMI was in males.

As shown in table 5, this study discovered that $59 \%$ subject had normal BMI. Besides, $12 \%$ subjects had underweight BMI consisting of $3 \%$ females ,and 20\% males. Subject with BMI status obesity was $11 \%$, and all of them was females.

Table 3 Energy Intake of Study Subjects

\begin{tabular}{|c|c|c|c|c|c|c|c|c|}
\hline \multirow[b]{2}{*}{$\begin{array}{c}\text { Age } \\
\text { (year) }\end{array}$} & \multicolumn{4}{|c|}{ Females } & \multicolumn{4}{|c|}{ Males } \\
\hline & $\begin{array}{c}\operatorname{Mean} \pm \mathrm{SD}^{*} \\
\left(\mathrm{kcal}^{* *}\right)\end{array}$ & $\begin{array}{c}\text { Max } \\
\text { (kcal) }\end{array}$ & $\underset{\text { (kcal) }}{\text { Min }}$ & $\begin{array}{c}\text { Mean } \\
\text { consumption } \\
\text { level } \\
\text { (\%RDA\#) }\end{array}$ & $\begin{array}{c}\text { Mean } \pm \text { SD } \\
\text { (kcal) }\end{array}$ & $\begin{array}{c}\text { Max } \\
\text { (kcal) }\end{array}$ & $\underset{\text { (kcal) }}{\text { Min }}$ & $\begin{array}{c}\text { Mean } \\
\text { consumption } \\
\text { level } \\
\text { (\%RDA) }\end{array}$ \\
\hline $19-29$ & $1585.23 \pm 492$ & 2485.8 & 111.3 & 83.5 & $2003 \pm 624$ & 3697.8 & 1124.3 & 82 \\
\hline $30-49$ & $1774.10 \pm 448$ & 2773.2 & 1147 & 93.7 & $1920.3 \pm 338$ & 2576.6 & 1307.3 & 80 \\
\hline $50-64$ & $1659.67 \pm 438$ & 2160.6 & 1214.4 & 91.2 & $1906.3 \pm 194$ & 2174.3 & 1695.8 & 92.5 \\
\hline Total & $1729.61 \pm 449$ & 2773.2 & 1111.3 & 91.6 & $1955.8 \pm 472$ & 3697.8 & 1124.3 & 82 \\
\hline
\end{tabular}

Note: * Standard Deviation, ${ }^{* *}$ kilocalories, \# Recommended Daily Allowances

Table 4 Frequency Distribution of Energy Intake Category

\begin{tabular}{lcccccc}
\hline \multirow{2}{*}{$\begin{array}{c}\text { Energi Intake } \\
\text { Category }\end{array}$} & \multicolumn{2}{c}{ Females } & \multicolumn{2}{c}{ Males } & \multicolumn{2}{c}{ Total } \\
\cline { 2 - 7 } & $\mathbf{n}$ & $\mathbf{\%}$ & $\mathbf{n}$ & $\mathbf{\%}$ & $\mathbf{n}$ & $\mathbf{\%}$ \\
\hline Low & 16 & 40 & 21 & 53 & 37 & 47 \\
Normal & 16 & 40 & 16 & 40 & 32 & 40 \\
Excess & 8 & 20 & 3 & 7 & 11 & 13 \\
Total & 40 & 100 & 40 & 100 & 80 & 100 \\
\hline
\end{tabular}


Table 4 Frequency Distribution of BMI Category

\begin{tabular}{lcccccc}
\hline \multirow{2}{*}{ BMI category } & \multicolumn{2}{c}{ Females } & \multicolumn{2}{c}{ Males } & \multicolumn{2}{c}{ Total } \\
\cline { 2 - 7 } & $\mathbf{n}$ & $\mathbf{0}$ & $\mathbf{n}$ & $\mathbf{\%}$ & $\mathbf{n}$ & $\mathbf{\%}$ \\
\hline Underweight & 1 & 3 & 8 & 20 & 9 & 12 \\
Normal & 18 & 45 & 29 & 73 & 47 & 59 \\
Overweight & 12 & 30 & 3 & 7 & 15 & 18 \\
Obesity & 9 & 22 & 0 & 0 & 9 & 11 \\
Total & 40 & 100 & 40 & 100 & 80 & 100 \\
\hline
\end{tabular}

\section{Discussion}

IThe results of this study showed that more than half of subjects had normal hemoglobin level. Approximately $23 \%$ subjects had anemia which consists of 11 females subjects, and 7 males subjects. The proportion subjects that had anemia were greater in females subjects (61\%). These findings are similar to those of Wolgemuth et al. ${ }^{1}$, Sinclair and Hinton ${ }^{8}$, Pasricha et al. $^{9}$ that prevalence of anemia was greater in females than males. Women are more susceptible to have anemia because of inadequate iron, and protein intake, inadequate absorption, or increase demand of iron as in menstrual period, pregnancy, and lactation. ${ }^{9}$

Despite most of study subjects had normal hemoglobin level category. About more than $90 \%$ subjects had marginal hemoglobin level between normal and low. It can be caused by the lack variation of food consumed by study subjects, such as lack of red meat, and vegetables consumption. This study's result similar to the findings in Kenyan workers. ${ }^{1}$

This study had $47 \%$ subjects who had deficiency energy intake based on RDA 2004. The recommendation requirement of energy intake of females subjects whose 19-29 age group is $1900 \mathrm{kcal}$. Females subjects whose age group 30-49 needs $1800 \mathrm{kcal}$ while subjects in age group of 50-64 needs 1750 $\mathrm{kcal}$. The requirement of energy intake of males subjects whose 19-29 age group is $2550 \mathrm{kcal}$. Males subjects whose age group 30-49 needs $2350 \mathrm{kcal}$ while subjects inage group of 50-64 needs $2250 \mathrm{kcal} .^{8}$ This study showed that subjects who had the lowest energy intake were age group 50-64. There is $5 \%$ reducing of energy requirements as it increases with age in 50-64 that may have contributed into the result of this study. ${ }^{7}$ Study had proven that energy intake deficiency leads to reduce energy production in body ; thus it results in lower productivity. ${ }^{3}$ If the amount of energy is not sufficient, our body will break down the energy reserves. ${ }^{2}$

Deficiency energy intake in the study subjects may have been caused by lacking knowledge of good nutrition. The highest educational level reached by this study subjects was senior high school and most of them had latest educational level in elementary school. As the increase of educational level, there is increase in health, and nutrition's knowledge. ${ }^{10}$ Low socioeconomic level may have influenced the ability to purchase food. Besides most of the study subjects only ate once or twice in a day with none or rare consumed snacks. This result was similar to those reported in factory's workers in Semarang.,4 Workers with most deficiency energy were also found in Kenyan workers. ${ }^{1}$

The proportion of the subjects that had exceeded energy intake was greater in females than males. These findings are similar to those study in Bangladesh. They stated that females workers who were better in knowledge, and understanding about relation between food, and health were able to try consuming healthy food.$^{10}$ Better nourished female workers can be caused by their role in foods preparation. Since their frequent access to food during its preparation may have contributed the additional quantities of calories to their diets. ${ }^{1}$

This study showed that $12 \%$ study subjects was underweight, $59 \%$ was normal, $18 \%$ was overweight, and $11 \%$ was obesity. The BMI is determined by the equilibrium of energy intake and physical activity. Work load of K3L workers were hygiene maintenance such as street cleaning, garbage accumulation and transport, drainage cleaning; also park maintenance such as watering, cleaning, weed cutting, soil crumbling, dried leaf cutting, fertilizing, and pest controlling. Low BMI status can be caused by the imbalance between less energy intake but more energy was used in the physical activities of workers. Meanwhile, 
study subjects which had normal BMI but low energy intake may have been caused by the difference in the work load proportion of each workers. Imbalance state between work load and working hours also may have contributed to this condition. These can be explained by workers with less work load but had the same working hours made the workers to have more less productive leisure time in work. Workers who BMI status is overweight and obesity can be explained by their exceeded energy intake with less energy used in work. Low work motivation or less work load than others may have contributed to this condition .

The result of this study was contrast with Utami $^{3}$ which stated that most of the factory workers had low BMI. However the pieces of study conducted by Adrianto and Ningrum ${ }^{11}$ towards Semarang factory workers and Mahardika and Roosita ${ }^{12}$ towards factory workers in West Java revealed similar results that most of their workers had normal BMI.

Thus, it can be concluded that most of K3L workers have normal hemoglobin level, deficiency energy intake, and normal BMI. Limitation of this study was the accuracy of 24 hours dietary recall which depends on study subjects' memories (recall bias ) and local language problem . It may have contributed in high subjectivity in data collection. Adjusting the eating habit of subjects and more complete food model could increase the accuracy of 24 hours dietary recall results. In order to increase worker productivity, it is suggested that the workers should be educated about dietary habit, healthy food resources and nutritional balance. Universitas Padjadjaran also should give extra feeding in between working hours so the increase of energy intake could increase work productivity. Besides Universitas Padjadjaran should implement further study about physical fitness of workers and the efficiency of work load and working hours. They could also give the workers additional job in their leisure time so the working time would be more efficient and may increase workers' income.

\section{References}

1. Wolgemuth JC, Latham MC, Hall A, Chesher
A, Crompton DW. Worker productivity and the nutritional status of Kenyan road construction laborers. Am J Clin Nutr.1982; 36(1):68-78.

2. Guyton AC, Hall JE. Textbook of medical physiology. 11 ed. USA: Saunders Co. University of Mississipi School of Medicine; 2005.p.79-80,864-75.

3. Utami SR. Status gizi, kebugaran jasmani dan produktivitas kerja pada tenaga kerja wanita. KEMAS. 2012;8(1):74-80.

4. Hapsari OB, Kartini A. Pengaruh minuman karbohidrat elektrolit terhadap produktivitas kerja. Journal of Nutrition College. 2013; 2(4):564-70.

5. Adi DPGS, Suwondo A, Lestyanto D. Hubungan antara iklim kerja, asupan gizi sebelum bekerja, dan beban kerja terhadap tingkat kelelahan pada pekerja shift pagi bagian packing PT. X, Kabupaten Kendal. Jurnal Kesehatan Masyarakat. 2013; 2(2):1-11

6. Adak DK, Gautam RK, Gharami AK. Assessment of nutritional status through body mass index among adult males of 7 tribal populations of Maharashtra, India. Mal J Nutr. 2006; 12(1):23-31.

7. Hardinsyah, Riyadi H, Napitupulu V. Angka kecukupan energi, protein, lemak dan serat makanan. Prosiding Widyakarya Nasional Pangan dan Gizi VIII. 2004:p.17-9.

8. Sinclair LM, Hinton PS. Prevalence of iron deficiency with and without anemia in recreationally active men and women. J Am Diet Assoc. 2005;105(6):975-8.

9. PasrichaSR, Drakesmith H,BlackJ, Hipgrave D, Biggs BA. Control of iron deficiency anemia in low- and middle-income countries. Blood. 2013;121(14):2607-17.

10. Alam N, Roy SK, Ahmed T, Ahmed AM. Nutritional status, dietary intake, and relevant knowledge of adolescent girls in rural Bangladesh. J Health Popul Nutr. 2010;28(1):86-94.

11. Adrianto EH, Ningrum DNA. Hubungan antara tingkat kesegaran jasmani dan status gizi dengan produktivitas kerja. KEMAS. 2010;5(2):145-50.

12. Mahardikawati VA, Roosita K. Aktivitas fisik, asupan energi, dan status gizi wanita pemetik teh di PTPN VIII Bandung, Jawa Barat. J Gizi Pangan. 2008;3(2):79-85. 